\title{
Ecological significance of the arthropod fauna from the Jurassic (Callovian) La Voulte Lagerstätte
}

Sylvain Charbonnier, Jean Vannier, Pierre Hantzpergue, and Christian Gaillard

Acta Palaeontologica Polonica 55 (1), 2010: 111-132 doi: http://dx.doi.org/10.4202/app.2009.0036

The La Voulte Lagerstätte is remarkable for its unique soft-bodied fauna (e.g., worms, coleoid squids) and its exceptionally preserved arthropods mainly found in small sideritic concretions. This arthropod fauna includes 30 different species assigned to the crustaceans, the thylacocephalans and the pycnogonids. Crustaceans are the most diversified group with 23 species distributed in a dozen families. Quantitative analyses based on 388 nodules reveals four dominant groups: (i) the enigmatic thylacocephalan arthropods (33\%), (ii) the Solenoceridae shrimps (22\%), (iii) the Coleiidae crustaceans (15\%), and (iv) the Penaeidae shrimps (10\%). Converging lines of evidence from depositional environment and modern analogues, indicate that this arthropod fauna probably inhabited a deep water setting most probably exceeding $200 \mathrm{~m}$ (= bathyal zone) under dysphotic or aphotic conditions. This new set of data sheds new light on the deep-sea colonisation by animal communities in the Mesozoic.

Key words: Arthropoda, Crustacea, Thylacocephala, Lagerstätte, Jurassic, Callovian, La Voulte, France.

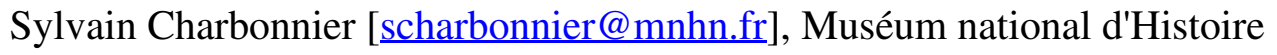
naturelle (MNHN), Département Histoire de la Terre, UMR 7207 CNRS, 8 rue Buffon, CP38, 75005 Paris, France ; Jean Vannier [jean.vannier@univ-lyon1.fr ], Pierre Hantzpergue [pierre.hantzpergue@univlyon1.fr] and Christian Gaillard [christian.gaillard@ univ-lyon1.fr], UMR 5125 PEPS, CNRS, Université Lyon 1, Campus de la Doua, Bâtiment Géode, 2 rue Raphaël Dubois 69622 Villeurbanne Cedex, France.

This is an open-access article distributed under the terms of the Creative Commons Attribution License (for details please see creativecommons.org), which permits unrestricted use, distribution, and reproduction in any medium, provided the original author and source are credited. 
Fof Full text $(2,643.8 \mathrm{kB})$ 